\title{
Çayırhan Termik Santralı Emisyonlarının Yöre Topraklarının Bazı Ağır Metal ve Kükürt Kapsamlarına Etkilerinin Belirlenmesi*
}

\author{
The Determination of the Effect of Cayirhan Coal-Fired Power Plant Emission on Heavy \\ Metals and Sulphur Contents of Regional Soils
}

\author{
Ayten KARACA ${ }^{1}$, Cafer TÜRKMEN ${ }^{2}$, Sevinç ARCAK ${ }^{1}$, Koray HAKTANIR ${ }^{1}$, \\ Bülent TOPÇUOĞLU ${ }^{3}$, Hakan YILDIZ \\ ${ }^{1}$ Ankara Üniversitesi, Ziraat Fak., Toprak Bölümü, Ankara \\ ${ }^{2}$ Onsekiz Mart Üniversitesi, Ziraat Fak., Toprak Bölümü, Çanakkale \\ ${ }^{3}$ Akdeniz Üniversitesi, Teknik Bilimler MYO, Çevre Kirlenmesi ve Kontrolü Programı, Antalya \\ ${ }^{4}$ Tarım ve Köyişleri Bakanlığı, TAGEM, Uzaktan Algılama Birimi, Ankara
}

\begin{abstract}
Özet: Bu araştırmada Çayırhan Termik Santralı baca gazı emisyonlarının çevre toprakları üzerine yapmış olduğu etkiler araştırılmıştır. Bu amaçla emisyonların hakim rüzgar yönünde hareket edeceği göz önüne alınarak güney doğu yönünde bulunan tarım alanlarından 20 adet, kuzey doğu yönünden santral merkez kabul edilmek üzere Beypazarı ilçesine doğru 7 adet ve hakim rüzgar yönünün tersi istikameti olan kuzey batı yönünden de 3 adet toprak örneği $0-20 \mathrm{~cm}$ derinlikten alınmıştır. Toprak örneklerinin $\mathrm{pH}$, organik madde ve toplam $\mathrm{Pb}, \mathrm{Cd}$, Ni ve $\mathrm{S}$ kapsamları belirlenmiştir.Kuzey doğu yönüne ait toprakların $\mathrm{pH}$ değerleri diğer yönlerin $\mathrm{pH}$ değerlerinden daha düşük olup, $\mathrm{pH}$ ile toplam kükürt, $\mathrm{Cd}$ ve $\mathrm{Pb}$ kapsamları arasında $\mathrm{P}<0.001$ düzeyinde önemli negatif ilişki belirlenmiştir. Her üç yönden alınan toprakların toplam $\mathrm{Pb}$ ve $\mathrm{Ni}$ kapsamları Toprak Kirliliği Kontrol Yönetmeliği sınır değerlerinin altında bulunmuştur ve henüz yukarıda belirtilen metallerin kirliliğinden söz etmek mümkün değildir. Buna karşın, hakim rüzgar yönünden alınan toprakların toplam Cd değerleri hakim rüzgar yönü tersinden alınan topraklara nazaran oldukça yüksek ve Toprak Kirliliği Kontrol Yönetmeliği sınır değerlerinin üzerinde bulunmuştur. Benzer şekilde, kuzey doğu yönüne ait toprakların hepsinde ve güney doğu yönüne ait toprakların büyük çoğunluğunda $S$ kirlenmesi ve hakim rüzgar yönü tersi olan kuzey batı yönünden alınan toprak örneklerinde de olası $\mathrm{S}$ kirlenmesi belirlenmiştir.
\end{abstract}

Anahtar Kelimeler: Çayırhan, termik santral, emisyon, toprak, ağır metal, kükürt.

Abstract: In this research, the effects of the emissions released by the Cayirhan Coal-Fired Power Plant on the soils were investigated. For this aim, taking into consideration that emissions would be transported in the prevailing wind direction, 20 soil samples from southwest fields, 7 samples from northwest fields in Beypazari township, 3 samples from northeast soils the position of which is in reverse direction to prevailing winds were taken at the depth of $0-20 \mathrm{~cm}$. Besides soil $\mathrm{pH}$ and organic matter contents, total $\mathrm{Pb}, \mathrm{Cd}, \mathrm{Ni}$ and $\mathrm{S}$ contents of the soil samples were also determined.pH values of the northwest soils were found to be lower than that of other soils and a significant negative correlation $(\mathrm{P}<0.001)$ was determined between total $\mathrm{S}, \mathrm{Cd}$ and $\mathrm{Pb}$ contents.Total $\mathrm{Pb}$ and $\mathrm{Ni}$ contents of the soils of the three directions were found to be below the limits set out by the Soil Pollution Control Regulation. Therefore, metal contamination in these soils is out of question. Whereas, total $\mathrm{Cd}$ of the soils in the prevailing wind direction were observed to be considerably high in comparison with those in opposite wind direction, and to be above the limits of the regulation. Similarly, total S contamination was determined to be in the northwest and the majority of the southwest soils and the northeast soils of opposite direction to prevailing winds.

Key words: Cayirhan, coal-fired power plant, emission, soil, heavy metal, sulphur.

\section{Giriş}

Termik santraller kömür, fuel-oil, motorin, doğal gaz ve jeotermal enerji kaynaklarının kullanılmasıyla elektrik enerjisinin üretildiği tesislerdir. Termik santraller; çabuk yapılabilirliği, ucuza mal edilmesi, düşük kaliteli kömürlerin değerlendirilmesi gibi getirdiği avantajlar nedeniyle elektrik üretiminde tercih nedenidir. Kömür yakıtlı termik santrallerin Türkiye'de ağırlıklı bir elektrik enerjisi üretim biçimi olarak seçilmesinin başlıca nedeni, kömürün fuel-oil veya doğalgaz gibi ülkemizde

\footnotetext{
* Bu çalışma Ankara Üniversitesi Bilimsel Araştırma Projeleri Müdürlüğü tarafından desteklenmiştir.
} 
pahalı ya da kıt olan yakıtlara göre daha ucuz olarak kabul edilmesidir. Ülkemizin hidroelektrik güç ile birlikte en önemli öz enerji kaynağı linyitlerdir. Ülkemiz linyitleri yüksek nem, kükürt ve kül içerikli olup, düşük 1sı değerlidirler ve büyük miktarda çevre kirliliğine neden olurlar.

Termik santrallerde elektrik üretmek amacıyla, öğütülmüss kömür kullanılmakta ve yakma sistemine bağlı olarak değişik atık malzemeler elde edilmektedir. Modern termik santrallerde en önemli atık malzeme, yanmadan dolayı baca tarafından çekilen gazlarla birlikte yukarıya sürüklenen çok ince kül parçacıklarıdır. Santrallerde yakılan kömürden arta kalan milyonlarca kül, cüruf ve partiküller birkaç yüz metre yükseklikte ve binlerce hektar genişlikte başka bir arazi üzerine depo edilerek, ormanları maki alanlarını, tarım kültürlerini ve yerleşim alanlarını yoğun kül emisyonu altında birakmaktadır (Pacyna, 1987).

Baca gazıyla yayılan külün yüzeyi $\mathrm{As}, \mathrm{Cd}, \mathrm{Cu}$ gibi metallerle yoğunlaşır ve hava akımlarıyla uzak mesafelere taşınırlar. Araştırmalar, santralden $30 \mathrm{~km}$ uzaklıkta, büyük partiküllerdeki As, Cd ve $\mathrm{Pb}$ konsantrasyonunun atmosferdeki normal seviyesine indiğini göstermektedir (Rosensthein, 1970).

Yapımları sırasında projelerinde hiç gözükmeyen birçok çevre sorunu termik santraller ile Türkiye gündemine girmiştir. Yüksek kullanım payına sahip fosil yakıtlı termik santraller hava, su ve toprak kirliliği ile ekolojik dengenin bozulmasına olumsuz etkilerde bulunmaktadır. Kömüre dayalı termik santrallerin çevreyi olumsuz yönde etkileyen asgari 13 faktör tespit edilmiş olup bunlar; baca gazları, kül stok sahasındaki küller, kül barajları, kül siloları, kül nakil bant hattı, hidrolik kül atma sistemi, santral sahası, dekapaj sahası, açık kömür işletme sahaları, kömür nakil yolları, kirli atık sular ve termal etkidir (Karaca, 1997).

Baca gazları, kömürle çalışan termik santrallerin, çevreyi en geniş ve şiddetli etkileyen olumsuz faktörüdür. Kömür yakıtlı termik santral bacalarından atmosfere atılan başlıca kirleticiler; karbonmonoksit (CO), karbondioksit $\left(\mathrm{CO}_{2}\right)$, kükürt oksitler (SOx), azot oksitler (NOx), hidrokarbon bileşikleri, ağır metaller ve partiküllerdir. Bunların yanı sıra fosil yakıt içinde bulunan radon ve uranyum gibi radyoaktif maddeler de az miktarda da olsa bulunur.

Tüm fosil yakıtların yanması ile $\mathrm{CO}_{2}$ oluşur, fakat enerji içeriği bazında, kömürün yanması fuel-oil'e göre $\% 25$, doğal gaza oranla ise $\% 50$ daha fazla $\mathrm{CO}_{2}$ çıkmasına neden olmaktadır. $\mathrm{CO}_{2}$ kontrolü ve önlenmesine yönelik teknolojiler ise pahalıdır.

Baca gazındaki SOx bileşikleri, kömür kükürtünün yanma sırasında oksitlenmesi neticesinde açığa çıkar. Kömürün yanması esnasında kükürt oksitlenerek $\mathrm{SO}_{2}$ açığa çıkar. Fosil yakıtların yakılmasından ortaya çıkan $\mathrm{SO}_{2}$ 'nin miktarı, kömür ve petroldeki kükürt oranına bağlıdır. Tahripkar olan $\mathrm{SO}_{2}$ 'den ziyade bunun oksitlenmesinden ortaya çıkan $\mathrm{SO}_{3}$ 'tür. Kükürtlü bileşikler insan sağlığına olduğu kadar bitki ve hayvan topluluklarına da zarar vermektedir. Kükürt oksitleri nemli ortamlarda yapraklarda asit halinde toplanıp, bitkinin köklerine inerek azotu indirgeyerek bakterilerin ölmesine yol açar ve toprağın asitliğini arttırır (Gürkan 1992).

Fosil yakıtların ağır metal içerikleri de, diğer kirleticilerde olduğu gibi yakıtın cinsine ve kaynağına göre değişmektedir. Yakıttaki elementin konsantrasyonu, kazan tipi baca gazı emisyonu kontrol aygıtının yapısı, termik santralden atmosfere verilen ağır metal emisyon miktarlarını belirler.

Ağır metallerin toprağa bulaşması genellikle doğrudan uygulama, emisyonların doğrudan depolanması veya organik materyallerin ilavesiyle olmaktadır. Gübrelerden, atık çamur kullanımından veya kentsel ve endüstriyel atık bileşenlerinden dolayı pek çok iz element ve ağır metal toprağa ilave olmaktadır (Hemida ve ark. 1997). Toprakta ağır metal hareketi ve alımına toprak pH'sı, toprak organik maddesinin kalite ve miktarı, kil mineralleri tipi ve kapsamı, KDK ve diğer toprak bileşenleri etki etmektedirler.

Adriano ve ark (1980), termik santrallerde kömürün yanması ile bacalardan salınan uçucu küllerin asit veya alkalinn karakterde olduğunu ve önemli miktarda $\mathrm{Cd}, \mathrm{Co}, \mathrm{Cu}, \mathrm{Fe}, \mathrm{Al}, \mathrm{Mn}, \mathrm{Mo}, \mathrm{Ni}$ ve $\mathrm{Zn}$ içerdiğini belirlemiştir. Araştırmacılar, ayrıca söz konusu metalleri içeren uçucu küllerin, toprağın kimyasal özellikleri ile mikrobiyal aktivite üzerine de olumsuz etkiler yapıp yapmadığını incelemişler ve uçucu kül ilavesiyle toprakta nitrifikasyonun azaldığını bulmuşlardır. 
Bunzl ve ark (1983), Leinigerwerk termik santralinde yaptıkları araştırmada 0.4, 0.8, 1.4, 2.7 ve $5.2 \mathrm{~km}$ mesafelerden toprak örnekleri ve 2 yıl süresince de 4 ayrı zamanda elektrostatik toplayıcılardan uçucu kül örnekleri alıp analiz etmişlerdir. Analiz sonuçlarına göre kül örneklerinin $\mathrm{Pb}$ içeriği $3680 \mathrm{mgkg}^{-1}$, Co içeriği $122 \mathrm{mgkg}^{-1}$ ve $\mathrm{Ni}$ içeriği $325 \mathrm{mgkg}^{-1}$ olarak saptanmıştır. Araştırmacılar sonuç olarak bu üç elementin santral etrafındaki dağılımının uzaklıkla ilişkisi olmadığını hatta santral topraklarının $\mathrm{Pb}$, Co ve $\mathrm{Ni}$ içeriklerinin kirlenmiş toprakların $\mathrm{Pb}$, Co ve $\mathrm{Ni}$ içerikleri ile aynı seviyede olduğunu belirtmişlerdir.

Mejsrik ve Suacha (1988), Çekoslovakya'da bulunan 3 ayrı termik santralden 1, 5, 10, ve 15 $\mathrm{km}$ uzaklıklardan 7 yıl boyunca toprak ve bitki örnekleri almışlar ve örneklerde $\mathrm{Co}, \mathrm{Cd}$, Ni ve $\mathrm{Zn}$ dağglımlarını araştırmışlardır. Araştırmacılar, incelenen 3 termik santral etrafındaki topraklarda ve bitkilerde belirli miktarlarda ağır metal birikiminin saptandığını ancak 7 yıllık izleme periyoduyla bu metal yı̆̆ılmasının kaynağının saptanamayacağını, bunun emisyonlardan olup olmadığını belirlemek için daha uzun süreler incelenme yapılması gerektiğini bildirmişlerdir.

Nuhoğlu (1993), Muğla-Kemerköy Termik santralinde yapmış olduğu çalışma sonucunda, topraktaki asitliğin termik santrallerin oluşturduğu hava kirliliği ile fazla ilgisi olmadığı gibi bir durum ortaya koymuştur. Araştırmacı ayrıca yöre topraklarının kalsiyum karbonatça zengin olmasının termik santrallerin oluşturduğu asit yağmurları tamponlayabileceğini de belirtmiş̧ir.

Martinez-Tarazona ve Spears (1996), Yorkshire Termik Santralinden aldıkları kömür, uçucu ve taban külü önekleri üzerinde 15 iz element (As, Ba, Cr, $\mathrm{Cu}, \mathrm{Mn}, \mathrm{Mo}, \mathrm{nb}, \mathrm{Ni}, \mathrm{Pb}, \mathrm{Rp}, \mathrm{Sr}, \mathrm{V}, \mathrm{Y}, \mathrm{Zn}$, $\mathrm{Zr}$ ) ve 10 makro element ( $\mathrm{Al}, \mathrm{Ca}, \mathrm{Fe}, \mathrm{K}, \mathrm{Mg}, \mathrm{Na}, \mathrm{P}, \mathrm{S}, \mathrm{Si}, \mathrm{Ti})$ için AAS ve XRF'de analizler yapmışlardır. Araştırmacılar her element için zenginleşme faktörünü hesaplamışlar ve $\mathrm{As}, \mathrm{Cu}, \mathrm{Mo}, \mathrm{Pb}$ ve Zn'nun uçucu küllerde zenginleştiğini tespit etmiş̧lerdir. Araştırmacılar ayrıca uçucu küllerin tane boyutunun düşmesi ile $\mathrm{As}, \mathrm{Cu}, \mathrm{Mo}, \mathrm{Pb}$ ve $\mathrm{Zn}$ 'nin konsantrasyonun arttığını bulmuşlardır.

Karaca (1997), Afşin-Elbistan Termik santralinde yapmış olduğu çalışmada genel olarak hakim rüzgar yönünden alınan örneklerin iz element ve ağır metal içeriklerini, çevre köylerden alınan örneklere kıyasla yüksek bulmuş, özellikle santrale yakın mesafelerde konsantrasyonlar oldukça artış göstermiştir. Yapılan korelasyon analizlerine göre, hakim rüzgar yönünde alınan toprakların üreaz, asit ve alkalin fosfataz aktiviteleri ile Fe hariç diğer bütün iz elementlerin ve ağır metal, azot, KDK arasında önemli negatif, organik madde ve $\mathrm{pH}$ ile de pozitif korelasyon belirlenmiştir.

Çancı (1998), Seyitömer termik santralı uçucu kül ve taban külü örnekleri ile santral civarındaki toprak örneklerinde AAS kullanarak $\mathrm{Pb}, \mathrm{Zn}, \mathrm{Cd}, \mathrm{Cu}$, Co analizlerini gerçekleștirmiș ve uçucu küllerin çevreyi kirletme eğilimini değerlendirmiştir. Araştırıcı toprak örneklerinin konsantrasyonlarını farklı ülkelerin tarım amaçlı olarak belirlenen üst limitleri ile karşılaştırmış, $\mathrm{Cd}$, $\mathrm{Cu}$ ve $\mathrm{Zn}$ konsantrasyonlarının verilen değerlerin altında kaldığını, Co ve Pb konsantrasyonlarının ise üst limit değerlerini aştığını tespit etmiştir.

Onacak (1999), Türkiye'deki 10 adet Termik Santralin 13 ünitesinde kömürlerin yanması sonucu oluşan katı atıkların çevreye etkilerini incelemiş ve 39 adet örneğin (beslenen kömür, uçucu kül ve taban külü) major ve iz element analizlerini XRF, ICP-AES ve ICP-MS kullanarak yapmıştır. $\mathrm{Bu}$ çalışmanın sonucunda termik santrallerin kömür örneklerinde $\mathrm{Cr}, \mathrm{Cs}, \mathrm{Mn}, \mathrm{Mo}, \mathrm{Ni}, \mathrm{Rp}, \mathrm{Th}, \mathrm{U}$ ve V içeriklerinin Swaine (1990) tarafından verilen dünya kömürlerinin çoğuna ait maksimum sınır değerleri aştığını tespit etmiştir. Termik santrallerin kömür, uçucu kül ve taban külü element analiz sonuçlarına göre hesaplanan kütle-denge değerleri ve uçucu kül / taban külü konsantrasyon oranlarına göre çoğu santralde $\mathrm{Zn}, \mathrm{Sn}, \mathrm{Pb}$, As, Mo ve Ge elementlerinin uçucu karakter gösterdikleri ve uçucu kül taneleri üzerinde önemli zenginleşme gösterdiklerini saptamıştır.

Haktanır ve ark (2006), Yatağan termik santrali çevresinden değişik mesafelerde tarım ve orman alanlarından (orman, 2 zeytinlik ve 17 tarım alanı) hem toprak hem de bitki örnekleri alıp ağır metal analizleri yapmışlardır. Araştırmacılar genelde santralin güney, güney batısı ve kuzeybatısındaki topraklarda ağır metal içeriğinin yüksek bulunduğunu ve bu değerlerin santrale uzaklığa değil hakim rüzgar yönlerine bağlı olduğunu belirlemişlerdir. 
Karaca ve ark (2007), Seyitömer termik santrali çevresi topraklarında yapmış oldukları çalışmada, araştırma topraklarının sadece \% 0.25'inde $\mathrm{Ni}$ ve \%13.68'inde Cr'un TKKY sınır değerlerinin altında olduğunu, toprakların çoğunluğunun $\mathrm{Ni}$ ve $\mathrm{Cr}$ 'ca yüksek değerler içerdiğini belirtmişlerdir. Araştırmacılar, santralin yakınında ve uzağında özellikle Batı yönünden alınan toprakların genel olarak düşük $\mathrm{Ni}$ içermeleri, ara noktalardan alınan topraklarda ise santralden uzaklaştıkça Ni değerlerinin artmasının, nikelin net bir şekilde santral baca gazının yayıldığı hakim rüzgar yönüne bağlı hareket etmediği şeklinde açıklamışlardır. Bu durumda toprakta mevcut yüksek $\mathrm{Cr}$ ve Nikelin kaynağının jeolojik araştırma yapılmadan santral emisyonlarından mı yoksa toprăğ oluşturan ana materyalden mi olduğu noktasında kesin bir ayrıma gitmenin mümkün olmadığını vurgulamışlardır.

Yukarıda belirtilen açıklamalar doğrultusunda linyit kömürü kullanarak enerji üretimi yapan Çayırhan Termik Santralinin çevresinde mevcut tarım topraklarının $\mathrm{pH}$, organik madde, ağır metal $(\mathrm{Pb}, \mathrm{Cd}, \mathrm{Ni})$ ve kükürt kapsamları üzerine olası etkilerinin ortaya konulması bu çalışmanın amacını oluşturmaktadır. $\mathrm{Bu}$ amaçla bölgede mevcut hakim rüzgar yönleri ve tersi yönlerde bulunan tarım topraklarından santral merkez kabul edilmek suretiyle belirli mesafe aralıklarından toprak örnekleri alınmış ve analiz edilerek irdelenmiştir.

\section{Materyal ve Yöntem}

\subsection{Santralın Coğrafik Yeri ve Tarımsal Durumu}

Çayırhan Termik Santralı Ankara'ya 123 km, Beypazarı'na 22 km, Nallıhan'a 35 km mesafededir. Santral mahalli, kömür kaynağına yakın seçildiği gibi soğutma suyunun sağlanacağı Sarıyar baraj gölüne yakın seçilerek kurulmuştur. Santral sahasının yüzölçümü $5.032 .000 \mathrm{~m}^{2}$ 'dir. Santralde dört adet ünite bulunmaktadır.

Santralın tüm ünitelerinde tüketilen linyit, Türkiye Kömür İşletmeleri (TKİ) Müessese Müdürlüğ̈̈'nden temin edilmektedir. Temin edilen kömür $800 \mathrm{t} / \mathrm{h}$ ve $1200 \mathrm{t} / \mathrm{h}$ kapasiteli taşıyıcı bantlarla kömür stok sahasına 5 adet park makinesi aracıllı̆̆ıla dökülmektedir. Homojen bir şekilde kazanda yakılmak üzere $1200 \mathrm{t} / \mathrm{h}$ kapasiteli taşıyıcı bantlarla kömür bunkerlerine gönderilmektedir.

Hava Kalitesinin Korunması Yönetmeliği (1986) uyarınca, $\mathrm{SO}_{2}$ emisyon sınır değerlerini aşan termik santrallerin desülfirizasyon tesislerinin kurulması zorunluluğu getirilmiștir. Çayırhan Termik Santralinin 4 ünitesinde de Baca Gazı Kükürt Arıtma Tesisi bulunmaktadır. Desülfürizasyon tesislerinde $\mathrm{SO}_{2}$ gazlarının tutulmasında yaş kireçtaşı-alçı yöntemi uygulanmaktadır. Ancak, bu yöntem $\mathrm{SO}_{2}$ emisyonunu giderirken saatte 50 ton gibi önemli bir ölçüde oluşan desülfojipsten dolay1 depolama problemlerine yol açmakta ve çevre kirliliği yaratmaktadır (Gençsoy ve Kefelioğlu 1994).

Denizden ortalama $500 \mathrm{~m}$ yükseklikte olan santral bölgesine ulaşım oldukça iyidir. Bölge, coğrafi durumu, morfolojik yapısı, iklim ve toprak faktörleri itibariyle tarıma elverişlidir. Bölgede kuru ve sulu tarım yapılmaktadır. Susuz arazilerde buğday, arpa gibi tahıl ürünleri yetiştirilmektedir. Sulu arazilerde ise sebzecilik (havuç, ispanak, yeşil soğan, turp, marul vd.), meyvecilik ve bağcılık yapılmaktadır. Bölgede hayvancılıkta gelişmiştir. Bölgede nüfusun büyük bir kısmı çitçilikle uğraşmaktadır.

Araştırma bölgesinde 2 büyük toprak grubunun hakim olduğu görülmektedir. Bunlar Kahverengi Orman toprakları ve Kahverengi topraklardır. Aynı zamanda alanda görülen diğer toprak grupları ise Kolüviyal topraklar, Alüviyal topraklar ve Çıplak Kaya ile Molozlardır. Bölge topraklarının çoğunluğu alt ve üst profilde ağır bünyeli, nötr ve hafif alkalin karakterde, kireçce zengin ve organik maddece fakirdir.

\subsection{Toprak Örneklerinin Alınması ve Analize Hazırlanması}

Araştırma kapsamında toprak örnekleri Ekim 2002 tarihinde alınmıştır. Örneklemeler santrale olan uzaklık, bakı ve hakim rüzgar yönü dikkate alınarak belirlenmiştir. Çayırhan termik santralı çevresindeki en yakın meteoroloji istasyonları Çayırhan, Nallıhan ve Beypazarın'da bulunmaktadır. 
Bunlardan sadece Beypazarı günün 24 saatinde saatlik rüzgar verilerini toplamaktadır. 5 yıllık ortalama hakim rüzgar yönü Beypazarı için $\mathrm{KD}$ ve $\mathrm{KB}$ istikametindedir.

Bölgedeki yüksek engebe ve derin vadiler nedeniyle Beypazarı meteroloji istasyonundan alınan rüzgar verilerinin Çayırhan çevresindeki durumu yeterince doğru yansıtmayacağı dikkate alınmış ve örnekleme yapmadan önce bölgeye yapılan ön keşif çalışmalarında hakim rüzgar yönü izlenmiş ve örnekleme yapılan sonbahar mevsimindeki hakim rüzgar yönü belirlenmiştir.

Bölgede hakim rüzgar yönü kuzey batıdan (KB) güney doğuya (GD) doğru olup, toprak örnekleri tarım alanlarından emisyonların hakim rüzgar yönünde hareket edeceği göz önüne alınarak güney doğudan (GD) 20 adet toprak örneği alınmıştır (8-27 nolu örnekler). Ayrıca Beypazarı meteroloji istasyonu kayıtlarında yer almayan ancak ön keşif çalışmalarında rüzgarın çoğunlukla estiği belirlenen kuzey doğu (KD) yönünden santral merkez kabul edilmek üzere Beypazarı ilçesine doğru 7 adet toprak örneği alınmıştır (1-7 nolu örnekler). Beypazarı meteroloji istasyonunca belirlenen 2. hakim rüzgar yönünde ise (güney batı) tarım alanları az olduğundan ve vadi içerisinde kaldığından örneklemeler yapılmamıştır. Hakim rüzgar yönünün tersi istikameti olan kuzey batı $(\mathrm{KB})$ yönünden de kontrol amaçlı 3 adet toprak örneği alınmıştır (28-30 nolu örnekler).

Her bir toprak örneği 0-20 cm derinlikten alınmıştır. Laboratuarda havada kurutulan toprak örnekleri öğütüldükten sonra $2 \mathrm{~mm}$ 'lik elekten elenerek naylon torbalarda muhafaza edilmiştir. Toprak örneklerinin alındı ̆̆ı noktalar Şekil 2'de verilmiştir.

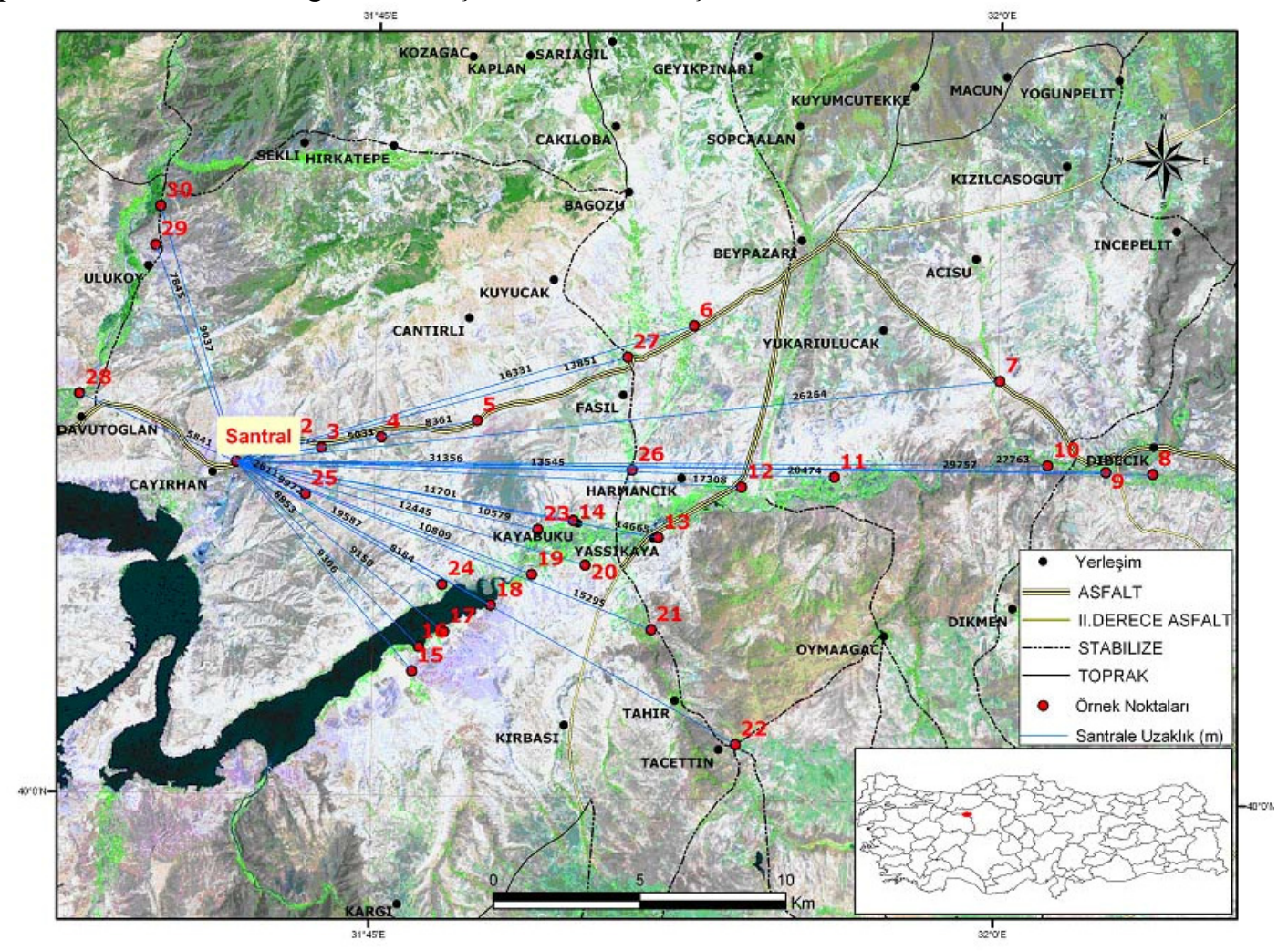

Şekil 2. Örnekleme noktalarının uydu görüntüsü.

Toprakların organik madde kapsamları Jackson (1962) tarafından bildirildiği şekilde WalkleyBlack yöntemine göre, toprak reaksiyonu $(\mathrm{pH})$ Richards (1954)'e göre 1:2,5 toprak/su süspansiyonunda, toplam kükürt 1 gr toprak örneğinde Eltra CS 500 Carbon Sulfur Determinator cihazında $1450{ }^{\circ} \mathrm{C}^{\prime}$ de yakılarak, toplam $\mathrm{Cd}, \mathrm{Pb}$ ve Ni Nitrik asit-hidroklorik asit karışımında $(1: 3 \mathrm{v} / \mathrm{v}$ oranında) yaş yakılan toprak örneklerinin Shimadzu AA-625-01 model Atomik Absorpsiyon Spektrofotometresinde (AAS) (Kacar 1995) ve alınabilir Cd, $\mathrm{Pb}$ ve $\mathrm{Ni}$ ise Lindsay ve Norvell (1978) 
tarafından belirtildiği şekilde DTPA+ $\mathrm{CaCl}_{2}$ ile ekstrakte edilmiş ve Shimadzu AA-625-01 model AAS cihazında belirlenmiştir.

\section{Bulgular ve Tartışma}

\subsection{Araştırma Topraklarının pH Değerleri}

Bu çalışmada 3 farklı yönden alınan örnekler ayrı ayrı ele alınarak değerlendirilmiştir.

Kuzey doğu yönünden alınan örneklerin (1-7 nolu örnekler) $\mathrm{pH}$ değerleri 7.12-7.57 arasında değişmekte olup, hafif alkalin karakter göstermektedir (Çizelge 1). Yapılan korelasyon analiz sonuçlarına göre örneklerin $\mathrm{pH}$ değerleri ile santrale olan uzaklık $(\mathrm{r}=0.742)$ ve toplam $\mathrm{Cd}(\mathrm{r}=0.651)$ arasında $\mathrm{P}<0.001$ düzeyinde önemli pozitif ve toplam kükürt $(\mathrm{r}=-0.944)$ arasında da $\mathrm{P}<0.001$ düzeyinde önemli negatif ilişki belirlenmiştir.

Güney doğu (GD) yönünden alınan örneklerin (8-27 nolu örnekler) pH değerleri 7.28-7.62 arasında değişmekte olup, hafif alkalin karakter göstermektedir. Yapılan korelasyon analiz sonuçlarına göre örneklerin $\mathrm{pH}$ değerleri ile diğer toprak özellikleri arasında istatistiksel olarak önemli sayılabilecek düzeyde bir ilişki belirlenmemiştir.

Hakim rüzgar yönü tersi olan Kuzey batı (KB) yönünden alınan toprak örneklerinin (28-30) pH değerleri ise 7.29-7.63 değerleri arasında olup, hafif alkalin ve alkalin karakter göstermektedir. Yapılan korelasyon analiz sonuçlarına göre örneklerin $\mathrm{pH}$ değerleri ile toplam $\mathrm{Pb}(\mathrm{r}=-0.974)$ arasında $\mathrm{P}<0.001$ düzeyinde önemli negatif ilişki belirlenmiștir.

Düşük $\mathrm{pH}$ gösteren toprakların hakim rüzgar yönü doğrultusunda olması ve $\mathrm{pH}$ 'nın asit karaktere doğru azalma gösterdiği örneklerde toprakların toplam kükürt ile $\mathrm{Cd}$ ve $\mathrm{Pb}$ değerlerinin daha yüksek olması ve düşük $\mathrm{pH}$ ile $\mathrm{SO}_{2}$ emisyonları ile doğrudan bir ilişki kurulması çok doğru bir yaklaşım olmayabilir. Ancak bu durumun aksini de söylemek zordur. Zira pH azalmalarının bulunduğu alanlardaki toprak örneklerinde Çayırhan termik santralinin kurulmasından önceki dönemlere ilişkin toprak fiziko-kimyasal verilerinin bulunmayışı bir yorum yapmayı güçleştirmektedir. Bu nedenle bu çalışmada yapılan örnekleme noktalarına ait elde edilen değerler, gelecekte bölgenin ve toprakların ekolojik değişimlerinin takip edilmesinde bir hareket noktası olarak ele alınabilir. Araştırma alanı ve Çayırhan termik santralinin çevre topraklarına etkisi ile ilgili bir çalışma bulunmamakta ancak, Yatağan termik santralinin emisyon zararlanmalarını ele alan Sarıgül (1991)'e göre, emisyon etkisi altında kalan orman serilerinde 0-5 cm'lik toprak katmanlarında asitleşme eğilimi göstermektedir.

\subsection{Araştırma Topraklarının Organik Madde (OM) Kapsamları}

Kuzey doğu yönünden alınan örneklerin (1-7 nolu örnekler) OM kapsamları \% 1.26-2.52 değerleri arasında değişiklik göstermiştir (Çizelge 1). Kültür topraklarının kapsadıkları OM miktarına göre sinıflandırılmasına göre; \% 1'den az OM içeriyorsa az humuslu, \% 1.1-2 orta humuslu, \% 2.1-5 fazla humuslu şeklindedir. Bu sınır değerlerine göre 1, 6 ve 7 nolu toprakların OM kapsamları \% 2'nin üzerinde olup OM'ce yeterlidir. 2, 3, 4 ve 5 nolu topraklarda \% 1-2 arasında OM içermekte olup orta humuslu toprak sınıfına girmektedir. Yapılan korelasyon analiz sonuçlarına göre bu yöndeki toprakların organik madde kapsamları ile diğer toprak özellikleri arasında istatistiksel olarak önemli sayılabilecek düzeyde bir ilişki belirlenmemiştir.

Güney doğu yönünden alınan örneklerin (8-27 nolu örnekler) organik madde kapsamları \% 0.49-2.44 arasında değişmektedir. Buna göre, 10, 11, 12, 14, 26 ve 27 nolu toprakların OM kapsamları \% 2'nin üzerinde olup OM'ce yeterlidir. Buna karşın 8, 9, 16, 20 ve 21 nolu topraklarda OM \% 1'in altında olup OM'ce yetersiz az humuslu topraklar sinifina girmektedir. Yapılan korelasyon analiz sonuçlarına göre örneklerin $\mathrm{OM}$ kapsamları ile toplam $\mathrm{Pb}(\mathrm{r}=0.501)$ arasında $\mathrm{P}<0.05$ düzeyinde ve toplam $\mathrm{Cd}(\mathrm{r}=0.800)$, toplam Ni $(\mathrm{r}=0.662)$ ve toplam $\mathrm{S}(\mathrm{r}=0.667)$ arasinda da $\mathrm{P}<0.001$ düzeyinde önemli pozitif ilişki belirlenmiştir. 
Çizelge 1. Araştırma topraklarının toplam iz element, ağır metal ve kükürt miktarları.

\begin{tabular}{|c|c|c|c|c|c|c|c|}
\hline $\begin{array}{l}\text { Örnek } \\
\text { No. }\end{array}$ & $\begin{array}{l}\text { Santrale uzaklık } \\
\text { (m) }\end{array}$ & $\begin{array}{l}\mathrm{pH} \\
1: 2,5 \text { toprak/su }\end{array}$ & $\begin{array}{c}\mathrm{OM} \\
\%\end{array}$ & $\begin{array}{c}\mathrm{Pb} \\
\mathrm{mgkg}^{-1}\end{array}$ & $\begin{array}{c}\mathrm{Ni} \\
\mathrm{mgkg}^{-1}\end{array}$ & $\begin{array}{c}\mathrm{Cd} \\
\mathrm{mgkg}^{-1}\end{array}$ & $\begin{array}{l}\mathrm{S} \\
\%\end{array}$ \\
\hline 1 & 1.596 & 7,34 & 2,17 & 49,8 & 26,9 & 4,9 & 2500 \\
\hline 2 & 2.100 & 7,12 & 1,50 & 50,9 & 30,2 & 4,6 & 3270 \\
\hline 3 & 2.953 & 7,44 & 1,34 & 18,6 & 22,3 & 3,8 & 1300 \\
\hline 4 & 5.031 & 7,29 & 1,26 & 52,0 & 28,6 & 4,8 & 3000 \\
\hline 5 & 8.361 & 7,27 & 1,93 & 58,6 & 20,3 & 5,0 & 2400 \\
\hline 6 & 16.331 & 7,49 & 2,52 & 38,8 & 30,6 & 4,7 & 950 \\
\hline 7 & 26.262 & 7,57 & 2,21 & 44,9 & 16,0 & 2,5 & 100 \\
\hline 8 & 31.356 & 7,5 & 0,89 & 24,0 & 19,2 & 2,3 & 110 \\
\hline 9 & 29.757 & 7,49 & 0,89 & 35,1 & 13,2 & 1,8 & 100 \\
\hline 10 & 27.763 & 7,35 & 2,02 & 13,6 & 45,1 & 3,0 & 310 \\
\hline 11 & 20.474 & 7,43 & 2,44 & 106 & 55,6 & 4,7 & 1146 \\
\hline 12 & 17.308 & 7,51 & 2,60 & 87,5 & 46,8 & 5,4 & 4630 \\
\hline 13 & 14.665 & 7,55 & 1,42 & 75,1 & 29,0 & 3,3 & 300 \\
\hline 14 & 11.701 & 7,51 & 2,21 & 64,0 & 12,4 & 4,0 & 3100 \\
\hline 15 & 9.306 & 7,32 & 1,21 & 17,1 & 10,7 & 2,9 & 480 \\
\hline 16 & 8.853 & 7,42 & 0,98 & 74,1 & 34,0 & 3,6 & 400 \\
\hline 17 & 9.150 & 7,38 & 1,02 & 59,1 & 22,8 & 3,3 & 400 \\
\hline 18 & 9.972 & 7,5 & 1,33 & 36,9 & 26,2 & 2,8 & 600 \\
\hline 19 & 10.809 & 7,65 & 1,21 & 68,9 & 30,5 & 3,7 & 100 \\
\hline 20 & 12.445 & 7,42 & 0,94 & 23,4 & 10,5 & 2,2 & 120 \\
\hline 21 & 15.295 & 7,59 & 0,49 & 32,6 & 7,8 & 2,2 & 100 \\
\hline 22 & 19.587 & 7,62 & 1,18 & 55,9 & 15,0 & 2,9 & 120 \\
\hline 23 & 10.579 & 7,38 & 1,14 & 59,3 & 14,7 & 2,3 & 700 \\
\hline 24 & 8.184 & 7,28 & 1,27 & 40,5 & 17,4 & 3,0 & 900 \\
\hline 25 & 2.611 & 7,57 & 1,43 & 30,8 & 28,0 & 4,2 & 100 \\
\hline 26 & 13.545 & 7,67 & 2,05 & 79,5 & 52,0 & 4,9 & 1500 \\
\hline 27 & 13.851 & 7,62 & 2,29 & 49,3 & 21,6 & 4,2 & 210 \\
\hline 28 & 9.037 & 7,29 & 0,95 & 26,8 & 6,2 & 2,1 & 76 \\
\hline 29 & 7.845 & 7,63 & 1,23 & 10,7 & 8,9 & 0,5 & 97 \\
\hline 30 & 5.841 & 7,54 & 2.11 & 11,3 & 4,4 & 1,7 & 120 \\
\hline
\end{tabular}

Hakim rüzgar yönü tersi olan Kuzey batı yönünden alınan toprak örneklerinin (28-30) organik madde kapsamları ise \% 0.95-2.11 değerleri arasında değișmektedir. 28 nolu toprak OM'ce yeterli (fazla humuslu toprak), 29 nolu toprak \% 1'den fazla OM içerip orta humuslu toprak ve 30 nolu toprak örneği de \%1'den az OM içermekte ve az humuslu toprak sınıfına girmektedir. Yapılan korelasyon analiz sonuçlarına göre bu yöndeki toprakların organik madde kapsamları ile diğer toprak özellikleri arasında istatistiksel olarak önemli sayılabilecek düzeyde bir ilişki belirlenmemiştir.

\subsection{Araştırma Topraklarının Toplam Pb Kapsamları}

Kuzey doğu yönünden alınan örneklerin (1-7 nolu örnekler) toplam Pb kapsamları 18.6-58.6 $\mathrm{mg} \mathrm{kg}^{-1}$ arasında değişmektedir (Çizelge 1). Yönetmelikte belirtilen değere göre ve aynı zamanda toprakta genel olarak kritik değer olarak kabul edilen $100 \mathrm{mg} \mathrm{kg}^{-1} \mathrm{~Pb}$ konsantrasyonu (Kloke, 1980) dikkate alındığında Kuzey doğu yönünden alınan toprakların toplam Pb kapsamları sınır değerlerinin altındadır. Araştırmada kullanılan KD yönü toprak örneklerinin toplam $\mathrm{Pb}$ kapsamları ile analizi yapılan diğer toprak özellikleri arasındaki ilişkileri saptamak amacıyla yapılan korelasyon analizi sonuçlarına göre; toprakların toplam Pb kapsamları ile diğer toprak özellikleri arasında istatistiksel olarak önemli sayılabilecek bir ilişki belirlenememiştir.

Güney doğu yönünden alınan örneklerin (8-27 nolu örnekler) toplam Pb kapsamları 13.60$106.00 \mathrm{mgkg}^{-1}$ arasında değişmektedir. 11 nolu örnekte belirlenen toplam Pb değeri kritik değer 


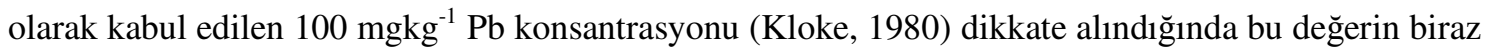
üzerindedir, ancak TKKY'inde belirtilen sınır değerin altındadır. GD yönünden alınan toprakların toplam $\mathrm{Pb}$ değerleri $\mathrm{KD}$ yönünden alınan topraklardaki gibi sınır değerleri aşmamaktadır. GD yönünden alınan toprakların toplam $\mathrm{Pb}$ kapsamları ile $\mathrm{OM}(\mathrm{r}=0.501)$, toplam $\mathrm{S}(\mathrm{r}=0.496)$, toplam $\mathrm{Cd}$ $(\mathrm{r}=0.667)$ ve toplam $\mathrm{Ni}(0.583)$ kapsamları arasında $\mathrm{P}<0.05$ düzeyinde önemli pozitif ilişki belirlenmiştir. Buna göre topraklarda henüz $\mathrm{Pb}$ sınır değerleri aşmamasına rağmen santral emisyonları ile yayılan gerek kükürt ve gerekse $\mathrm{Cd}$, Ni gibi metallerle $\mathrm{Pb}$ arasında pozitif ilişki bulunması birinin artığı yerde diğerlerinin de artış gösterdiğini düşündürmektedir.

Hakim rüzgar yönü tersi olan Kuzey batı yönünden alınan toprak örneklerinin (28-30) toplam $\mathrm{Pb}$ kapsamları ise 10.70-26.80 mg kg${ }^{-1}$ değerleri arasında değişmektedir. Bu yöndeki topraklarda belirlenen $\mathrm{Pb}$ değerleri de sınır değerlerin altındadır. Yapılan korelasyon analiz sonuçlarına göre örneklerin toplam $\mathrm{Pb}$ değerleri ile $\mathrm{pH}(\mathrm{r}=-0.974)$ arasında $\mathrm{P}<0.001$ düzeyinde önemli negatif ilişki belirlenmiştir.

Yüzey topraklarına $\mathrm{Pb}$ bulaşmasında temel etkenin atık çamurların kullanılması, yol kenarlarındaki topraklarda taşıtların yol açtığı bulaşma olarak ifade edilmesine karşın, endüstriyel işletmelerden de önemli oranlarda Pb kirlenmesi olmaktadır (Kabata-Pendias ve Pendias 1985). Metal işletme endüstrilerinden kaynaklanan ve işletmelerin çevresindeki yüzey topraklarında Kanada'da 291-12123 mg kg ${ }^{-1} \mathrm{~Pb}$ (John ve ark. 1975), Yunanistan'da 1250-18500 mgkg ${ }^{-1} \mathrm{~Pb}$ (Nakos 1979), Hollanda' da 628-1334 $\mathrm{mgkg}^{-1} \mathrm{~Pb}$ (Harmsen 1977) ve İngiltere'de 500-6500 $\mathrm{mgkg}^{-1} \mathrm{~Pb}$ (Miesch ve Huffman 1972) gibi çok yüksek miktarlarda Pb kirlenmesi belirlenmiştir.

Toprakların toplam $\mathrm{Pb}$ kapsamlarına ilişkin pek çok değer bulunmaktadır. Aktaş (1995), toprakta 2-200 mg kg ${ }^{-1}$ değerleri arasında $\mathrm{Pb}$ bulunduğunu belirtirken, Schwartman ve ark. (1982), podzol toprakların 30-100 mg kg-1 Pb içerdiğini belirtmişlerdir. Aubert ve Pinta (1979) ise kirlenmemiş topraklarda $10-80 \mathrm{mg} \mathrm{kg}^{-1} \mathrm{~Pb}$ saptadıklarını, santral yakınlarındaki topraklarda da bu değerlere yakın değerler bulduklarını ve kıyaslama yapıldığında $\mathrm{Pb}$ birikiminin henüz olmadığını belirtmişlerdir. Haktanır ve ark. (1995), Ankara bölgesinde trafiğe yakın topraklarda $120 \mathrm{mg} \mathrm{kg}^{-1} \mathrm{~Pb}$, trafikten uzak ve kirlenmemiş alanlardan alınan topraklarda ise $25 \mathrm{mg} \mathrm{kg}^{-1} \mathrm{~Pb}$ belirlediklerini rapor etmişlerdir.

Toprak Kirliliği Kontrol Yönetmeliğinde (TKKY) pH's1 6'nın üzerindeki topraklarda $\mathrm{Pb}$ için belirtilen sınır değer $300 \mathrm{mgkg}^{-1}$ 'dır. Genel olarak her üç yönden alınan topraklarda belirlenen $\mathrm{Pb}$ değerleri, $\mathrm{Pb}$ kirlenmesi yönünden kritik değer olarak kabul edilen $100 \mathrm{mg} \mathrm{kg}^{-1}$ 'in (Kloke 1980) ve TKKY sınır değerlerinin altında bulunmuştur ve henüz bir Pb kirliliğinden söz etmek mümkün değildir. Ancak, hakim rüzgar yönüne ters yönden alınan topraklardaki toplam $\mathrm{Pb}$ kapsamları hakim rüzgar yönü topraklarının çoğunluğunun içermiş olduğu Pb kapsamlarının oldukça altında olması, santralde uzun dönem içerisinde çevreye $\mathrm{Pb}$ kirlenmesinin olabileceği ihtimalini yükseltmektedir.

\subsection{Araştırma Topraklarının Toplam Ni Kapsamları}

Kuzey doğu yönünden alınan örneklerin (1-7 nolu örnekler) toplam Ni kapsamları 16.00$30.60 \mathrm{mgkg}^{-1}$ arasında değişmektedir (Çizelge 1). Toprak Kirliliği Kontrol Yönetmeliğinde (TKKY) pH'sı 6'nın üzerindeki topraklarda Ni için belirtilen sınır değer $75 \mathrm{mg} \mathrm{kg}^{-1}$ 'dir (Çizelge 9). Yönetmelikte belirtilen değere göre ve aynı zamanda toprakta genel olarak kritik değer olarak kabul edilen $50 \mathrm{mg} \mathrm{kg}^{-1} \mathrm{Ni}$ konsantrasyonu (Kloke, 1980) dikkate alındığında Kuzey doğu yönünden alınan toprakların toplam Ni kapsamları sınır değerlerinin altındadır.

Tarım topraklarında Ni kapsamı 2-1000 mg kg-1 arasında ve ortalama $50 \mathrm{mg} \mathrm{kg}^{-1}$ olarak belirtilmiştir. Schwartman ve ark. (1982), Almanya topraklarının ortalama $10-50 \mathrm{mg} \mathrm{kg}^{-1} \mathrm{Ni}$ içerdiğini belirtirken, Bunz ve ark. (1983), termik santral çevresindeki topraklarda $5-40 \mathrm{mg} \mathrm{kg}{ }^{-1} \mathrm{Ni}$ saptadıklarını belirtmişlerdir. Hakerlerler ve ark. (1995), GAP bölgesi topraklarında 11.37-60.23 mg $\mathrm{kg}^{-1}$ arasında Ni bulunduğunu belirtmişlerdir.

Araştırmada kullanılan KD toprak örneklerinin toplam Ni kapsamları ile analizi yapılan diğer toprak özellikleri arasındaki ilişkileri saptamak amacıyla yapılan korelasyon analizi sonuçlarına göre; 
Toprakların toplam Ni kapsamları ile toplam $\mathrm{Cd}(\mathrm{r}=0.689)$ arasında $\mathrm{P}<0.001$ düzeyinde önemli pozitif ilişki belirlenmiştir.

Güney doğu yönünden alınan örneklerin (8-27 nolu örnekler) toplam Ni kapsamları 7.80$52.00 \mathrm{mg} \mathrm{kg}^{-1}$ arasında değişmektedir. 11 ve 26 nolu örneklerde belirlenen toplam Ni değerleri kritik değer olarak kabul edilen $50 \mathrm{mg} \mathrm{kg}^{-1} \mathrm{Ni}$ konsantrasyonu (Kloke, 1980) dikkate alındığında kritik değerin biraz üzerindedir, ancak TKKY'inde belirtilen sınır değerin altındadır. GD yönünden alınan toprak örneklerinin toplam Ni kapsamları ile OM $(r=0.662)$, toplam $\mathrm{Zn}(\mathrm{r}=0.944)$ ve toplam $\mathrm{Cd}(\mathrm{r}=$ 0.714) kapsamları arasında $\mathrm{P}<0.001$ düzeyinde ve toplam $\mathrm{Pb}(0.587)$ kapsamı arasında da $\mathrm{P}<0.05$ düzeyinde önemli pozitif ilişki belirlenmiştir. Buna göre topraklarda henüz Ni sınır değerleri aşmamasına rağmen santral emisyonları ile yayılan gerek kükürt ve gerekse $\mathrm{Cd}, \mathrm{Pb}$, gibi metallerle $\mathrm{Ni}$ arasında pozitif ilişki bulunması ( $\mathrm{Pb}$ da olduğu gibi) birinin artığı yerde diğerlerinin de artış gösterdiğini düşündürmektedir.

Hakim rüzgar yönü tersi olan Kuzey batı yönünden alınan toprak örneklerinin (28-30) toplam $\mathrm{Ni}$ Kapsamları ise 4.40-8.90 mg kg${ }^{-1}$ değerleri arasında değişmektedir. Bu yöndeki topraklarda belirlenen toplam Ni değerleri de sınır değerlerin altındadır. Yapılan korelasyon analiz sonuçlarına göre örneklerin $\mathrm{Ni}$ değerleri ile diğer toprak özellikleri arasında istatistiksel olarak önemli sayılabilecek bir ilişki belirlenememiştir.

Toprakların yüksek Ni içeriği ve nikelce zenginleşmesi genel olarak, serpantin kayaları üzerinde oluşmuş topraklarda, fosforlu gübrelemenin çok yoğun bir şekilde yapıldığı ve atık çamurların gübre amaçlı uygulandığı tarım topraklarında ve endüstriyel işletmeler etrafındaki topraklarda görülmektedir (Kabata-Pendias ve Pendias 1985).

Hutchinson ve Tam (1981), termik santral topraklarının Ni kapsamının uzaklığa bağlı olarak değiştiğini ve termik santrale $3 \mathrm{~km}$ mesafede $3000 \mathrm{mg} \mathrm{kg}^{-1} \mathrm{Ni}$ ve $35 \mathrm{~km}$ mesafede de $160 \mathrm{mgkg}^{-1} \mathrm{Ni}$ saptandığını belirtmişlerdir. Çiçek ve Koparal (2004) Tunçbilek Termik santrali çevresinde yaptıkları araştırmada toprakların Ni kapsamları 20.1-372 mg kg olduğunu belirtmişlerdir. Çayırhan termik santrali çevresinden alınan topraklarda ise bu kadar yüksek değerlerde Ni saptanmamıştır. Her üç yönden alınan topraklarda belirlenen Ni değerleri (11 ve 26 nolu örnekler hariç), nikel kirlenmesi yönünden kritik değer olarak kabul edilen $50 \mathrm{mgkg}^{-1}$ 'in (Kloke 1980) ve TKKY sınır değerlerinin altında bulunmuştur ve henüz bir Ni kirliliğinden söz etmek mümkün değildir.

\subsection{Araştırma Topraklarının Toplam Cd Kapsamları}

Kuzey doğu yönünden alınan örneklerin (1-7 nolu örnekler) toplam Cd kapsamları 2.5-5.0 mg kg-1 arasında değişmektedir (Çizelge 1). Toprakta bulunan toplam Cd miktarı $0.01-7 \mathrm{mg} \mathrm{kg}^{-1}$ arasında olup, tipik ortalama değerin ise $0.06 \mathrm{mg} \mathrm{kg}^{-1}$ düzeyinde olduğu belirtilmiştir (Alloway 1968). Moen ve ark. (1986), kirlenmemiş topraklardaki Cd miktarının 0.01-1 $\mathrm{mg} \mathrm{kg}^{-1}$ arasında olduğunu belirtmiştir. Mc Laughlin ve Sings (1999), Cd ile ilgili sınır değerlerin ülkelere göre değiştiğini ve bu sınır değerlerinin; Danimarka, Finlandiya ve İsveç'de 0.5, Fransa'da 2, Almanya'da 1.5, İspanyada 1, İngiltere' de 3 ve ABD'de de $20 \mathrm{mg} \mathrm{kg}^{-1}$ kuru madde olarak kabul edildiğini belirtmişlerdir.

Toprak Kirliliği Kontrol Yönetmeliğinde pH'sı 6'nın üzerindeki topraklarda Cd için belirtilen sınır değer $3 \mathrm{mg} \mathrm{kg}^{-1}$ 'dır. Buna göre Kuzey doğu yönünden alınan toprakların toplam Cd kapsamları 7 nolu örnek hariç yönetmelik sınır değerlerinin üzerindedir. Araştırmada kullanılan KD yönü toprak örneklerinin toplam Cd kapsamları ile analizi yapılan diğer toprak özellikleri arasındaki ilişkileri saptamak amacıyla yapılan korelasyon analizi sonuçlarına göre; Toprakların toplam Cd kapsamları ile $\mathrm{pH}(\mathrm{r}=-0.651)$ ve santrale olan uzaklık $(\mathrm{r}=-0.668)$ arasında $\mathrm{P}<0.001$ düzeyinde önemli negatif ve toplam $\mathrm{S}(\mathrm{r}=0.742)$ ve toplam $\mathrm{Ni}(\mathrm{r}=0.689)$ kapsamları arasında $\mathrm{P}<0.001$ düzeyinde önemli pozitif ilişki belirlenmiştir.

Güney doğu yönünden alınan örneklerin (8-27 nolu örnekler) toplam Cd kapsamları 1.80-5.40 $\mathrm{mg} \mathrm{kg}^{-1}$ arasında değişmektedir. 11, 12, 13, 14,16,17, 19, 25, 26 ve 27 nolu örneklerde belirlenen toplam $\mathrm{Cd}$ değerleri yukarıda belirtilen sınır değerlerin üzerinde olup Cd birikimi söz konusudur. GD 
yönünden alınan toprakların toplam Cd kapsamları ile $\mathrm{OM}(\mathrm{r}=0.800)$, toplam $\mathrm{S}(\mathrm{r}=0.613)$, toplam $\mathrm{Pb}$ $(\mathrm{r}=0.667)$ ve toplam $\mathrm{Ni}(0.714)$ arasında $\mathrm{P}<0.001$ düzeyinde önemli pozitif ilişki belirlenmiştir.

Hakim rüzgar yönü tersi olan Kuzey batı yönünden alınan toprak örneklerinin (28-30) toplam Cd kapsamları ise $0.5-2.1 \mathrm{mg} \mathrm{kg}^{-1}$ değerleri arasında değişmektedir. Bu yöndeki topraklarda belirlenen $\mathrm{Cd}$ değerleri sınır değerlerin altındadır. Yapılan korelasyon analiz sonuçlarına göre örneklerin toplam $\mathrm{Cd}$ değerleri ile diğer toprak özellikleri arasında istatistiksel olarak önemli sayılabilecek bir ilişki belirlenememiştir. Christensen (1989), toprakta Cd ve Zn için dağılım katsayısının pH'ya bağımlı değiştiğini, pH'nın bir birimlik değişiminde Cd dağılım katsayısının 4 kat arttığını Zn'nun da Cd'a göre daha duyarlı olduğunu ve dalgalı dağılımlar gösterdiğini belirtmiştir. Kızılkaya (1998), Samsun Azot Sanayi ile Karadeniz Bakır işletmeleri çevresindeki tarım topraklarında Cd birikimi olduğunu ve Cd dağılımını etkileyen temel toprak özelliklerinin $\mathrm{pH}$ ve kireç olduğunu belirtmiştir. Connor ve ark. (1976) ve Anderson ve ark. (1975) Cd, F gibi element konsantrasyonlarının kömürle çalışan termik santral yakınlarında arttığını, bunun sebebinin de santral emisyonlarının olduğunu belirtmişlerdir.

Genel olarak hakim rüzgar yönünden alınan toprakların toplam $\mathrm{Cd}$ değerleri hakim rüzgar yönü tersinden alınan topraklara nazaran oldukça yüksek bulunmuştur. Bu da Cd'un Pacyna (1987)'ın belirttiği gibi rüzgar yönüne bağlı olarak emisyonlarla çevreye yayıldığını doğrulamaktadır. Pacyna (1982), Avrupa ülkelerinde kömürle çalışan termik santrallerin atmosfere verdiği ağır metal ve iz element miktarlarını, linyitin içerdiği uçucu kül yüzdesine bağlı olarak emisyon faktörü ile hesaplamıştır. Buna göre, Türkiye'de bulunan termik santrallerin kullandıkları linyitlerin çok fazla miktarda kül içermesinden dolayı emisyonların ağır metal ve iz element miktarlarının da çok yüksek olduğunu belirtmiştir. Çiçek ve Koparal (2004) Tunçbilek termik santrali çevresinde yaptıkları araştırmada topraklarda 1.4-21,7 mg kg${ }^{-1}$ arasında değişen Cd değerleri saptamışlar ve kritik seviyenin $3 \mathrm{mg} \mathrm{kg}^{-1}$ olduğunu belirtmişlerdir.

Araştırma bölgesinin vadi içerisinde yer alması ve Beypazarı tarafından gelen rüzgar ile tersi yönden esen 2. hakim rüzgar yönünün vadi üzerinde karşılaşıp belirli bir alanda emisyonların topraklara çökelmiş olabileceği düşünülmektedir. Şöyle ki toplam $\mathrm{Cd}$ konsantrasyonlarının yüksek bulunduğu topraklarda toplam $\mathrm{S}$ kapsamları da yüksek bulunmuş, aynı zamanda bu topraklarda $\mathrm{pH}$ değerlerinde bir azalma söz konusudur. Toprak reaksiyonu asit karaktere doğru gittikçe topraklarda kadmiyumun mobilitesinin arttığı bilinmektedir. Bütün bunlara rağmen Cd fazlalığının bulunduğu topraklarda Çayırhan termik santralinin kurulmasından önceki dönemlere ilişkin verilerin bulunmayışı kesin yorum yapmayı güçleştirmektedir. Toprak pH'sında da açıklandığı gibi bu çalışmada yapılan örnekleme noktalarına ait elde edilen değerler, gelecekte bölge topraklarında meydana gelecek değişimlerin takip edilmesinde veri tabanı oluşturacaktır.

\subsection{Araştırma Topraklarının Toplam Kükürt Kapsamları}

Kuzey doğu yönünden alınan örneklerin (1-7 nolu örnekler) toplam S kapsamları 100-3270 $\mathrm{mg} \mathrm{kg}^{-1}$ arasında değişmektedir (Çizelge 1). Ilıman bölge topraklarında toplam S içeriği 50-400 mgkg ${ }^{1}$ değerleri arasındadır (Aktaş 1995). Moen ve ark. (1986), Hollanda'da "Toprak Koruma" adıyla çıkarılan kanunda toplam S'e ilişkin 3 ayrı başlangıç değerinin bulunduğunu rapor etmişlerdir. Buna göre; toplam S miktarı $2 \mathrm{mg} \mathrm{kg}^{-1}$ olan topraklar "kirletilmemiş" olarak nitelendirilirken, $20 \mathrm{mg} \mathrm{kg}^{-1} \mathrm{~S}$ içeren topraklarda olası bir bulaşma tehlikesine karşı araştırma yapılması gerekliliği vurgulanırken, $200 \mathrm{mg} \mathrm{kg}{ }^{-1}$ ' $1 \mathrm{n}$ üstünde ise toprağın temizlenmesinin zorunlu olduğunu belirtmektedirler. $\mathrm{Bu}$ değerlere göre KD yönü topraklarının 7 nolu örnek hariç hepsinde önemli ve ciddi biçimde $S$ kirlenmesi söz konusudur (Çizelge 1).

Araştırmada kullanılan KD yönü toprak örneklerinin toplam S kapsamları ile analizi yapılan diğer toprak özellikleri arasındaki ilişkileri saptamak amacıyla yapılan korelasyon analizi sonuçlarına göre; Toprakların toplam S kapsamları ile santrale olan uzaklık $(\mathrm{r}=-0.821)$ ve $\mathrm{pH}(\mathrm{r}=-0.944)$ arasında $\mathrm{P}<0.001$ düzeyinde önemli negatif, toplam $\mathrm{Cd}(\mathrm{r}=0.742)$ ile de $\mathrm{P}<0.001$ düzeyinde önemli pozitif ilişki belirlenmiştir. 
Güney doğu yönünden alınan örneklerin (8-27 nolu örnekler) toplam S kapsamları 100-4630 $\mathrm{mgkg}^{-1}$ arasında değişmektedir. Yukarıda belirtilen kritik değerlere göre; 8, 9, 19, 20, 21, 22 ve 27 nolu örneklerde olası S kirlenmesi söz konusudur, diğer örnekleme noktalarının topraklarında ise ciddi şekilde S kirlenmesi belirlenmiştir. GD yönünden alınan toprakların toplam S kapsamları ile $\mathrm{pH}(\mathrm{r}=-$ 0.692) kapsamları arasında $\mathrm{P}<0.001$ düzeyinde önemli negatif, organik madde $(\mathrm{r}=0.670)$, toplam $\mathrm{Cd}$ $(\mathrm{r}=0.594)$ ve toplam $\mathrm{Pb}(\mathrm{r}=0.494)$ arasında ise $\mathrm{P}<0.05$ düzeyinde önemli pozitif ilişki belirlenmiştir.

Hakim rüzgar yönü tersi olan Kuzey batı yönünden alınan toprak örneklerinin (28-30) toplam $\mathrm{S}$ kapsamları ise 76-120 mg kg${ }^{-1}$ değerleri arasında değişmektedir. KB yönü örneklerinde de olası $\mathrm{S}$ kirlenmesi kritik değer olan 20 'in üzerinde $\mathrm{S}$ belirlenmiştir ve bu alanlarda da uzun süreli araştırma yapılması gerekmektedir. Yapılan korelasyon analiz sonuçlarına göre örneklerin toplam S içerikleri ile diğer toprak özellikleri arasında istatistiksel olarak önemli sayılabilecek düzeyde bir ilişki belirlenmemiştir.

Alpacar (1989), termik santrallerin bacalarından $\mathrm{SO}_{2}$ ve $\mathrm{NO}_{x}$ gibi gazların çıkarak çevreye yayıldığını ve bu gazların asit yağmurlarının oluşumunda birinci kaynak olduğunu açıklamıştır. Fabrika bacalarından çıkan kükürt hakim rüzgarlarla ortalama 2-7 gün içerisinde atmosfere taşınmakta, atmosferdeki su partikülleri ve diğer bileşenlerle tepkimeye girerek sülfüroz asit ve sülfirik asit oluşturmakta, aynı şekilde toprağa inmekte ve taban suyu ile birleşerek sülfirik asit şekline dönüşen $\mathrm{SO}_{2}$ 'nin bitki köklerini tahrip ederek besin ve su iletim sistemlerinin görevlerini yapamaz duruma getirmeleri sonucu kitlesel şoklu orman ölümlerinin meydana geldiğini belirtmiştir. Karaca (1997), Afşin-Elbistan termik santralı baca gazı emisyonlarının toprakların toplam S dağılımı üzerine yaptığı araştırmada, özellikle santrale $2 \mathrm{~km}$ mesafeye kadar ve $30 \mathrm{~km}$ 'deki örneklerde önemli $\mathrm{S}$ birikimlerinin olduğunu ve derinliğe bağlı olarak $S$ miktarının azaldığını ve toprak yüzeyindeki birikmenin belirgin olduğunu belirtmiştir. Pacyna (1987), termik santralden $30 \mathrm{~km}$ mesafeden sonra iz element birikiminin arttığını belirtmiştir.

Kerme Körfezi'nin kuzeyinde yer alan Yatağan'da kurulmuş olan termik santralın baca gazları, yöreye hakim kuzey rüzgarları altında Bencik Dağı ile Sepetçi Dağı üzerinde bulunan kızılçam ormanlarının ve çevredeki tarım alanlarının şiddetle etkilenmesine neden olmuştur. Bencik Dağı - Sepetçi Dağı arazisinde henüz kurumamış olan kızılçam ormanlarında ise önemli bir artım düşüklügüu belirlenmiştir. Bu ormanlardaki kızılçamların yapraklarında kükürt oranı 1,600 - 3,800 mg $\mathrm{kg}^{-1}$ arasında olup, yıllık halkaları çok daralmıştır. Bu şekilde etkilenmiş olan kızılçam ağaçlarının kerestelik odun kalitesinde de önemli ve olumsuz değişiklikler olmaktadır. Asit yağmurlarından etkilenen toprakların reaksiyonunun yer yer 4.3 PH'ya $(0.1 \mathrm{~N} \mathrm{KCl}$ ' de) düştüğü bildirilmiştir. Bu da ağaçların beslenmesini etkileyen ve kurumalarını kolaylaştıran bir faktördür. Ayrıca çevredeki köylerde; zeytin, antep fıstığı, incir, badem ağaçları, üzüm bağları, sebzecilik ve yaygın tarım ürünü olan tütüncülük şiddetle zarar görmüştür.

Türkiye'de ilk defa Çayırhan Termik Santralında baca gazından kükürt arıtma tesisleri yapılmış olup, 26 Mart 1992 tarihi itibariyle ticari işletmeye başlamıştır. Tesis baca gazı içinde 21000 $\mathrm{mg} / \mathrm{m} 3$ e varan kükürdü \% 95 oranında temizleyebilecek şekilde dizayn edilmiştir (Gürkan 1992). Gençsoy ve Kefelioğlu (1994), Çayırhan Termik Santralında kullanılan kömürün içindeki S miktarının \% 4.65 gibi yüksek değerde olması nedeniyle yanma sonucu bacadan çevreye, iki ünitenin de tam yükte çalışması durumunda, saatte yaklaşık 30 ton $\mathrm{SO}_{2}$ gazı verileceğini hesaplandığını ve bunun üzerine santrale bir baca gazı kükürt arıtma tesisinin kurulmasının kararlaştırıldığını belirtmişlerdir. Çayırhan Termik Santralı Baca Gazı Kükürt Arıtma Tesisinde konvensiyonel kireç taşı prosesi uygulanmaktadır. Bu proses, yıkama maddesi olarak kireçtaşı çözeltisi kullanan ve son ürün olarak alçıtaşı üreten bir yaş yakma sistemidir. Ülkemizde ilk olarak Çayırhan termik santralında kullanılan baca gazı desülfürizasyon tesisi, eski teknolojinin seçimi nedeni ile kendinden bekleneni verememiştir (Tusiad 2005). 


\subsection{Termik Santral Kömür ve Uçucu Külüne Ait Kimyasal ve İz Element-Ağır Metal Sonuçları}

Külün çeşitli özelliklerini etkileyen başlıca faktörler, yakılan kömürün bileşimi ve yapısı, yanma tekniği ve şartları ile külün tutulma şeklidir. Pulvarize kömürün 1100-1600 derece yanmasıyla oluşan atıklar \% 80-90 oranında baca gazları ile sürüklenir ve uçucu kül olarak bilinir. Diğger kısım da cüruf veya dip külü olarak kalır. Genellikle yakıttaki toksik ve iz elementler yüksek sıcaklıkta kısmen buharlaşır ve soğuma sırasında kül tanecikleri üzerinde yoğunlaşır. Uçucu olmayan elementler ise daha çok kül yapısında kalır. Bütün bunlara dayanarak santralden çıkan uçucu küllerin etki ve içeriklerinin tanımlanmasında yararlı olması amacıyla santralde kullanılan kömüre ait kimyasal bileşimler elde edilmiştir. Çayırhan termik santralinde kullanılan kömüre ait analiz sonuçları Çizelge 2'de, santralden çıkan kül örneklerinin bazı kimyasal ve iz element-ağır metallere ait ortalama değerler ise Çizelge 3'de verilmiştir. Çizelge 2'ye göre, santralde kullanılan kömür yüksek nem, kül ve kükürt içermektedir.

Çizelge 2. Kömüre ait analizler.

\begin{tabular}{|l|l|l|}
\hline Özellik & A Sektörü & B Sektörü \\
\hline Kömür yayılım alanı (km2) & 60 & 50 \\
\hline Isı Değeri (kcal/kg) & 2557 & 2839 \\
\hline Kömürün yoğunluğu (ton/m3) & 1.40 & 1.40 \\
\hline Ortalama kömür derinliği (m) & 247.69 & 333.88 \\
\hline Ortalama kömür kalınlığ1 (m) & 2.98 & 2.64 \\
\hline Su (\%) & 21.71 & 26.44 \\
\hline Kül (\%) & 34.35 & 25.36 \\
\hline Toplam S (\%) & 4.04 & 2.79 \\
\hline
\end{tabular}

Çizelge 3. Kül örneklerine ait analiz sonuçları.

\begin{tabular}{|l|l|}
\hline Yapılan Analiz & Dĕger \\
\hline $\mathrm{pH}$ & 12.55 \\
\hline $\mathrm{OM}(\%)$ & 0.034 \\
\hline $\mathrm{N}(\%)$ & 0.013 \\
\hline Toplam S (\%) & 1.111 \\
\hline Toplam Cd $\left(\mathrm{mg} \mathrm{kg}^{-1}\right)$ & 12.7 \\
\hline Toplam Pb (mg kg & -1 \\
\hline Toplam Ni $\left(\mathrm{mg} \mathrm{kg}^{-1}\right)$ & 149.6 \\
\hline Alınabilir Cd $\left(\mathrm{mg} \mathrm{kg}^{-1}\right)$ & 347.2 \\
\hline Alınabilir $\mathrm{Pb}\left(\mathrm{mg} \mathrm{kg}^{-1}\right)$ & 0.29 \\
\hline Alınabilir Ni $\left(\mathrm{mg} \mathrm{kg}^{-1}\right)$ & 1.05 \\
\hline
\end{tabular}

Santralden çıkan kül örneğinin pH değeri 12.55 olup (Çizelge 3) alkalin karakter göstermektedir. Uçucu küllerin asit veya alkalin karakterde olması içeriği üzerinde etkili olmaktadır. Picthel (1989), alkalin uçucu küllerin asitlere oranla daha fazla iz element ve ağır metal içerdiğini belirtmiştir. Araştırmacı, alkalin karakterdeki uçucu külün $26 \mathrm{mg} \mathrm{kg}^{-1} \mathrm{Cd}, 110 \mathrm{mgkg}^{-1} \mathrm{Cu}, 123700 \mathrm{mg}$ $\mathrm{kg}^{-1} \mathrm{Fe}, 210 \mathrm{mg} \mathrm{kg}^{-1} \mathrm{Mn}, 94 \mathrm{mg} \mathrm{kg}^{-1} \mathrm{Ni}, 940 \mathrm{mg} \mathrm{kg}^{-1} \mathrm{Zn}$, asit küllerin ise $3 \mathrm{mg} \mathrm{kg}^{-1} \mathrm{Cd}, 84 \mathrm{mg} \mathrm{kg}^{-1} \mathrm{Cu}$, $27900 \mathrm{mg} \mathrm{kg}^{-1} \mathrm{Fe}, 140 \mathrm{mg} \mathrm{kg}^{-1} \mathrm{Mn}, 49 \mathrm{mg} \mathrm{kg}^{-1} \mathrm{Ni}$ ve $69 \mathrm{mg} \mathrm{kg}^{-1} \mathrm{Zn}$ içerdiğini belirtmiştir. Kautz ve ark. (1975), Almanya' da bulunan termik santralden aldıkları uçucu küllerin 320-6500 Pb, 20-220 Co ve $200-1200 \mathrm{mg} \mathrm{kg}^{-1} \mathrm{Ni}$ içerdiğini belirtmişlerdir.

Theis ve Wirth (1977), 11 kül örneğinde $30-1120 \mathrm{~Pb}$ ve $90-600 \mathrm{mg} \mathrm{kg}^{-1} \mathrm{Ni}$ belirlediklerini ve alkalin karakterdeki küllerin ağır metal içeriklerinin asit nitelikli olanlara oranla çok daha fazla olduğunu açıklamışlardır.

Çayırhan termik santralinden çıkan uçucu küller bir depoda toplanmakta ve buradan da iletim bantları yardımıyla kül depolama sahalarına gönderilmektedir. Bu depoda zaman zaman doldurma, boşaltma ve özellikle bakım esnasında büyük miktarda uçucu kül çevreye yayılmaktadır (Anonymous 1989). Kül depolama sahaları ve arazide oluşturulan kül dağlarının yanı sıra uçucu küller, 
elektrofilitrelerdeki çok küçük kaçaklarla da çevrenin kirlenmesine neden olmaktadır. Kömür yakıtlı termik santrallerden kaynaklanan uçucu küllerin birçok toksik element içerdiği bilinmektedir. Cüruf ve iri parçacıklar yakma fırınından alındığında, buharlaşabilen elementler cüruf üzerine yoğunlaşamazlar. Bu nedenle, uçucu kül parçacıklarının üzerinde adsorbe ve konsantre olarak, külden küle büyük değişiklik gösteren bir yüzey katmanı oluştururlar. Bu bağlamda, uçucu küllerde bulunan bazı iz element ve ağır metaller, yüksek çözünürlükleri nedeniyle olumsuz çevresel etkiler yaratma potansiyeline sahiptir.

Kömürün yanması ile buharlaşan uçucu bileşikler baca gazındaki küçük taneciklerde yoğunlaşır. Baca gazı ile yayılan külün yüzeyi $\mathrm{As}, \mathrm{Cd}, \mathrm{Cu}$ gibi elementlerle yoğunlaşır ve santralden yayılan küçük partiküller hava akımlarıyla çok uzak mesafelere taşınırlar. Büyük partiküllerdeki As, $\mathrm{Pb}, \mathrm{Cd}$ konsantrasyonları ise düşüktür ve santral yakınlarında birikim gösterir. Araştırmalar, As, Ni $\mathrm{Cd}, \mathrm{Pb}$ konsantrasyonunun atmosferdeki normal seviyesine indiğini göstermiştir (Rosenshtein 1970). Türk linyitleri yüksek nem ve kül içerikli olup düşük 1sı değerlidirler. Bu nedenle yanmaları sonucu çevreye önemli miktarda iz element ve ağır metal yayınımı olmaktadır (Eskikaya, 1988).

\section{Sonuç ve Öneriler}

Çayırhan Termik Santralı, Çayırhan ilçesi yerleşim yeri ile iç içe bulunmaktadır. Aynı zamanda santral bacalarından çıkan emisyonlar rüzgarın etkisiyle çevresinde yer alan tarım topraklarına ulaşmaktadır. Bu çalışma yerel halkın ve kamu kurumlarının isteği üzerine başlatılmıştır.

Çalışma, santralin baca gazı emisyonlarından kaynaklanabilecek olası ağır metal kirliliğini ortaya koymak amacıyla yapılmıştır. Araştırma kapsamında elde edilen ve önemli sayılabilecek sonuçlar aşağıda özetlenmiştir:

1. Kuzey doğu yönü topraklarının $\mathrm{pH}$ değerleri diğer yönlerin $\mathrm{pH}$ değerlerinden daha düşük olup belirgin bir fark görülmektedir. Düşük $\mathrm{pH}$ gösteren toprakların hakim rüzgar yönü doğrultusunda olması $\mathrm{SO}_{2}$ emisyonları ile bir etkileşim olduğunu düşündürmekte ise de bu kesin yargıya ulaşmak, zaman boyutunda veri eksikliği nedeniyle çok doğru bir yaklaşım olmayabilir. Ancak güncel verilerin 1şı ğında bu durumun aksini de söylemek zordur. Araştırma bölgesinde pH azalmalarının bulunduğu alanlardaki toprak örneklerine ilişkin toprak fiziko-kimyasal verilerinin Çayırhan termik santralinin kurulmasından önceki dönemlere ulaşmaması bir yorum yapmayı güçleştirmektedir.

2. Toprak örnekleri organik madde bakımından da homojen olmayıp genellikle yeterli ve orta yeterli düzeyde OM kapsamaktadır.

3. Her üç yönden alınan topraklarda belirlenen toplam $\mathrm{Pb}, \mathrm{Ni}, \mathrm{Cu}$ ve $\mathrm{Zn}$ değerleri, Toprak Kirliliği Kontrol Yönetmeliği sınır değerlerinin altında bulunmuştur ve henüz $\mathrm{Pb}, \mathrm{Ni}, \mathrm{Cu}$ ve $\mathrm{Zn}$ kirliliğinden söz etmek mümkün değildir. Ancak, hâkim rüzgar yönüne ters yönden alınan topraklardaki toplam $\mathrm{Pb}, \mathrm{Ni}, \mathrm{Cu}$ ve $\mathrm{Zn}$ kapsamları hâkim rüzgar yönü topraklarının çoğunluğunun içermiş olduğu miktarların oldukça altında olması, uzun dönem içerisinde halen bulaşma etkisi gözlenen santral çevresi topraklarında bu metallerce kirlenmenin olabileceği olasılığını yükseltmektedir.

4. Kuzey doğu yönünden alınan toprakların (7 nolu örnek hariç) ve Güney doğu yönünden alınan 11, 12, 13, 14, 16, 17, 19, 25, 26 ve 27 nolu örneklerde saptanan toplam Cd değerlerinin yönetmelik sınır değerlerinin üzerinde olması, bölgede $\mathrm{Cd}$ birikimi tehlikesini işaret etmektedir. Genel olarak hâkim rüzgar yönünden alınan toprakların toplam $\mathrm{Cd}$ değerleri hâkim rüzgarın ters yönünden alınan topraklara nazaran oldukça yüksek bulunmuştur. Bu durum çevresel bakımdan en dikkatle izlenmesi gereken bu ağır metalin bölgesel bir risk faktörü olabileceğini düşündürmektedir.

5. Kuzey doğu yönü topraklarının (7 nolu örnek hariç) hepsinde dikkati çeken S bulaşması olup önemli düzeyde bir kirlenme söz konusudur. Güney doğu yönünden alınan 8, 9, 19, 20, 21, 22 ve 27 nolu örneklerde de olası S kirlenmesi söz konusudur, diğer örnekleme noktalarının topraklarında ise ciddi şekilde $S$ kirlenmesi belirlenmiştir. Hâkim rüzgâra ters olan kuzey batı yönü örneklerinde de olası S kirlenmesi kritik değeri olan $20 \mathrm{mg} \mathrm{kg}^{-1}$ 'in üzerinde $\mathrm{S}$ belirlenmiştir ve bu alanlarda da uzun süreli araştırma yapılması gerekmektedir. 
Araştırma sonuçlarının genel bir değerlendirmesi yapılacak olursa; araştırma bölgesinin vadi içerisinde yer alması ve Beypazarı yönünden gelen rüzgar ile aksi yönden esen 2. hakim rüzgar yönünün vadi üzerinde karşıllaşıp belirli bir alanda emisyonların topraklara çökeltmiş olabileceği düşünülmektedir. Şöyle ki toplam Cd konsantrasyonlarının yüksek bulunduğu topraklarda toplam $\mathrm{S}$ kapsamları da yüksek bulunmuş, aynı zamanda bu topraklarda $\mathrm{pH}$ değerlerinde bir düşme söz konusudur. Ayrıca emisyon taşınım mekanizmasında $\mathrm{SO}_{2}$ emisyonları ile birlikte ağır metal taşıyan ince partiküllerin dağılımının benzerlik gösterdiği düşünülebilir. Bütün bunlara rağmen kısa bir izleme periyodu ile topraklara $\mathrm{Cd}$ ve $\mathrm{S}$ yığılmasının kaynağının saptanması mümkün değildir ve bu yığılmanın santral emisyonlarından $\mathrm{m}$ i ileri geldiği yoksa jeolojik kökenli mi olduğunu belirleyebilmek için daha uzun süreli araştırmalara gerek vardır. Aynı zamanda $\mathrm{Cd}$ ve $\mathrm{S}$ fazlalığının bulunduğu topraklarda Çayırhan termik santralinin kurulmasından önceki dönemlere ilişkin verilerin bulunmayışı kesin yorum yapmayı güçleştirmektedir.

Bu çalışmada yapılan örnekleme noktalarına ait elde edilen değerler, gelecekte bölge topraklarında meydana gelecek değişimlerin takip edilmesinde veri tabanı oluşturacaktır. Sonuç olarak, araştırma sonuçları genel olarak bölgede ağır metal ve alınabilir kükürt yönünden yararlı olabilecek veri tabanı oluşturulması için iyi bir başlangıç olmuştur. Bu çalışma sonuçlarının bölgede bundan sonra yapılacak çalışmalarda temel veri oluşturacağı, örnekleme alanlarının GPS değerlerinin olması nedeniyle sorunların bu noktalara kolaylıkla erişilmesini sağlayacağı ve sorunları giderilmesi için yapılacak düzenlemeleri kolaylaştıracağı düşünülmektedir. Uzun süreli ve santralin bütün yönlerinden alınacak örneklemelerle santralden kaynaklanabilecek element kirliliğinin ortaya konması daha doğru olacaktır. Esasen ülkemizde mevcut olamayan izleme ağının bütün risk bölgelerinde oluşturulması ve zamansal izlenme verilerinin elde edilmesi gerekmektedir.

\section{Kaynaklar}

Adriano, D.C., Page, A.L., Elseewi, A.A., Chang, A.C. and Straugham, I. 1980. Utilization and disposal of fly ash and other coal residues in terrestrial ecosystems. A review. J. Environ. Qual., 9:333-444.

Aktaş, M. 1995. Bitki besleme ve toprak verimliliği. A.Ü.Z.F. Yayın No: 1429, Ders Kitabı: 416, Ankara.

Alloway, W.H. 1968. Agronomic controls over environmental cycling of trace elements. Adv. Argon. 20: 235-274.

Alpacar, N. 1989. Asit yağmurlarının ormanlar üzerindeki etkileri. Beşinci bilimsel ve teknik çevre kongresi, 5-8 Haziran, Adana.

Anonymous 1989. TEK işletme ve bakım idaresi başkanlığı santraller işletme ve bakım müdürlüğü raporu (yayınlanmamış).

Anderson, B.M., Keith, J.R. and Connor, J.J. 1975. Antimony, Arsenic, Germenium, Lithium, Mercury, Selenium, Titanium and Zinc in soil of the powder river basin. Second annual progress report. US Geol. Survey Open-file Report No. 75: 50-57.

Aubert, H. and Pinta, M. 1979. Trace metals in soil. Elsevier Sci. Publ. Co., Amsterdam.

Christensen, T.h. 1989. Cadmium sorption at low concentration: VIII. Correlation with soil parameters. Water Air Soil Pollut. 44: 71-82.

Bunzl, K., Rosner, G. and Schmindt, W. 1983. Distribution of lead, cobalt and nikel in the soil around a coal fired power plant. Z. Pflanenernaehr. Bodenk, 146: 705-713.

Connor, J.J., Anderson, B.M., Keith, J.R. and Boerngen, J.G. 1976. Soil and grass chemistry near the four corners power plant. Third annual Progress report. U.S. Geol.

Çanc1, B. 1998. Geochemical assessment of environmental effects of fly ash from Seyitömer (Kütahya) thermal power plant. Msc Thesis, İstanbul.

Eskikaya, T. 1988. Kömürdeki iz elementler ve çevre kirliliği. Çevre 89 5. Bilimsel ve Teknik Çevre Kongresi Kitab1, 857-868. 
Gençsoy, T. Ve Kefelioğlu, S. 1994. Termik Santrallerde baca gazı kükürt arıtma tesisleri. Türkiye 6. Enerji Kongresi Teknik Oturum Tebliğ 2: 166-171.

Gürkan, S. 1992. Çayırhan linyitlerinden kostik yıkama yöntemiyle mineral maddenin giderilmesi. Yüksek Lisans Tezi, Gazi Üniversitesi, Ankara.

Hakerlerler, H., Taysun, A., Okur, İ. ve Arslan, S. 1992. GAP bölgesi topraklarının ağır metallerinin birikimi. Tr. J. Of Enginereing of Environ. Sci. 19: 423-431.

Haktanır, K., Arcak, S., Erpul, G. ve Tan, A. 1995. Yol kenarındaki topraklarda trafikten kaynaklanan ağır metallerin birikimi. Tr. J. of Eng. Of Environ. Scien. 19: 423-431.

Haktanır, K., Karaca, A., Ok, S., Arcak, S., Türkmen, C., Topçuoğlu, B. ve Türeli, F. 2006. Muğla Yatağan Termik Santral Emisyonlarının Etkisinde Kalan Tarım ve Orman Topraklarının Kirlilik Veri Tabanının Oluşturulması ve Vejetasyon Etkilerinin Araştırılması. A.Ü. Bilisel Araştırma Projeleri, Ankara.

Harmsen, K. 1977. Behaviour of heavy metals in soils. Doctoral Thesis, Centre for Agric. Public. And Documents, Wageningen, 170.

Hava Kalitesi Korunması Yönetmeliği, 1986. 2.11.1986 tarihli ve 19269 Sayılı Resmi Gazete.

Hemida, S.K., Omar, S.A. and Abdel-Mallek, A.Y. 1997. Microbial populations and enzyme activity in soil treated with heavy metals. Water, Air, and Soil Pollution, 95: 13-22.

Hutchinson, T.C. and Tam, D. 1981. Extrem metal and acidity tolerance in the alga chlorella saccharophila isolated from polluted Sudbory soils. Can. J. Bot.59.

Jackson, M.L. 1962. Soil chemical analysis. Prentice - Hall, Inc. New York.

John, M.K., Van Laerhoven, C.J. and Cross, C.H. 1975. Cd, Pb and Zn accumulation in soil near a smelter coplex. Environ. Lett. 10, 25.

Kabata-Pendias, A. and Pendias, H. 1985. Trace elements in soils and plants. CRC Pres, Inc. Boca Raton, Florida.

Kacar, B. 1995. Toprak Analizleri. A.Ü.Z.F. Eğitim, Araştırma ve Geliştirme Vakfı Yayınları No: 3, 627-629, Ankara.

Karaca, A. 1997. Afşin-Elbistan termik santralı emisyonlarının çevre topraklarının fiziksel, kimyasal ve biyolojik özellikleri üzerine etkileri. Ankara Üniv. Fen Bil. Ens., Ankara. Doktora Tezi.

Karaca, A., Turgay, O.C., Karaca, S., Sağlam, M., Türkmen, F., Deviren, S. ve Türkmen, N. 2007. Seyitömer termik santrali emisyonlarının çevre toprakları üzerine etkiler. Proje, Yayınlanmamış, Ankara.

Kautz, K., Kirsch, H. and Laufhütte, D.W. 1975. Über die spurenelementgehalte in steinkohlen und den daraus entsehenden reingastauben. VGB Kraftwerkstechnik. 55: 612-676.

Kızılkaya, R. 1998. Samsun Azot Sanayi (TÜGSAŞ) ve Karadeniz Bakır İşletmeleri (KBİ) çevresindeki tarım topraklarında ağır metal birikiminin toprakların bazı biyolojik özellikleri üzerine etkisi. Ankara Üniv. Fen Bil. Ens., Ankara. Doktora Tezi.

Kloke, A. 1980. Orientierungtaden für tolerierbare gesamtghalte einger elemente in kulturboden. (Richwerte 80). Biologische Bundesantait for Land und Forstwirstchaft, Berlin.

Lindsay, W.L. and Norvell, W.A., 1978. Development of a DTPA soil test for $\mathrm{Zn}, \mathrm{Fe}, \mathrm{Mn}$ and $\mathrm{Cu}$. Soil Sci. Amer. J. 42 (3): 421-28.

Martinez-Tarazona, M.R. and Spears, D.A. 1996. The fate of trace elements and bulk minerals in pulverized coal combustion in a power station. Fuel Processing Technology, 47:79-92.

Mc Laughlin, M.J. and Sings, B.R., 1999. Cadmium in soils and plants. Volume 85. Kluwer Academic Publishers. Dordrecht/Boston/London.

Mejsrik, V. and Suacha, J. 1988. Concentration of Co, Cr, Cd, Ni and $\mathrm{Zn}$ in crop plants cultivated in the viciny of coal firewd power plant. The Science of the Environment, 72: 57-67.

Miesch, A.T. and Huffman, C. 1972. Adundance and distribution of lead, zinc, cadmium and arsenic in soils in Helena Valley Montana Area Environmental Pollution study. Environ. Protec. Agency, Research Triangle Park. N.C. 65. 
Moen, J.E.T., Cornet, J.P. and Evers, C.W.A. 1986. Soil protection and remedial actions. Crkia for decision making and standarization of requirements. 441-448. İn: Contaminated soil (ed. J.W. Assink and W,J, Wanderbink) Martinus Nijhot Dordiecht).

Nakos, G. 1979. Lead pollution. Fate of lead in the soil and its effects on pinus halepensis. Plant and soil. 53: 427-431.

Nuhoğlu, Y. 1993. Muğla Kemerköy termik santralinin oluşturacağı çevre kirliliğinin ormanlar üzerindeki etkileri. İstanbul Üniv., Fen Bil. Enstitüsü, Doktora tezi, İstanbul.

Onacak, T. 1999. Türkiyedeki termik santrallara beslenen kömürlerin ve yanma sonucu oluşan katı atıkların çevresel etkileri. Hacettepe Üniv., Fen Bil. Enstitüsü, Doktora tezi, Ankara.

Pacyna, J.M. 1982. Trace element emissions from coal and oil power plants in Eurape methodology of calculations. Norwegian Ins. For Air Research. Nilu Supplement Til Technics Raport No. 5/82. Ref. 24781.

Pacyna, J.M. 1987. Atmospheric emissions of As, Cd, Pd, and $\mathrm{Hg}$ from high temperature processes in power generation and industry. Ed. T.C. Hutchinson and K.M. Meema, John Wiley\&Sons Ltd.

Pacyna, J.M. and Nriagu, J.O. 1987. Atmoshferic emissions of $\mathrm{Cr}$ from natural and anthropogenic sources. $\mathrm{Cr}$ in the natural and human environments. (Ed. J.O. Nriago and E. Nieboer. John Willey and Sons Ltd. Inc.).

Picthel, J.R. 1989. Microbial Respiration in Fly Ash/ Sewage Sludge Amended Soils. Environ. Poll., 63, 225-37.

Richards, L.A., 1954. Diagnosis and improvement of saline and alkalin soils. U.S. Dept. Agr. Handbook, No.60, 110-8pp.

Rosenshtein, J.S. 1970. Sanitary toxicological assesment of low concentrations of $\mathrm{As}_{2} \mathrm{O}_{3}$ in the athmosphere. G.G. Sanit., 35(1): 15-20.

Sarıgül, M. 1991. Hava kirliliğinin Muğla-Yatağan yöresinde orman toprağı ve ağaçları üzerine etkisi. Ormancılık Araştırma Ens. Teknik Bülten, No. 217-248.

Schwartmann, W., Fischer, W.R. and Fecther, H. 1982. Spurenelemente in bodensequenzen. I. Zwei Brunerde-Podzol-Sequenzen aus fonschieferschutt. Z. Pflanzenern. Bodenk. 145: 181-196.

Swaine, D.J. 1990. Trace Elements in Coal, Butterworths, London, England, 278 pp.

Theis, T.L.and Wirth 1977. Sorptive behaviour of trace metals on fly ash in aqueous systems. Environ. Sci. Tech., 11: 1096-1100.

TUSİAD 2005. http://www.tusiad.org/turkish/rapor/enerji/html/sec16.html.

Türk Tabipleri Birliği 2000. Yatağan'da hava kirliliğinin değerlendirilmesi. TTB Raporu, yayınlanmamış. 